\title{
THE INTRODUCTION OF INNOVATIVE CONCEPTS IN THE MANAGEMENT SYSTEM OF THE SANATORIUM-RESORT ENTERPRISE IN THE CONTEXT OF ENSURING SOCIO- ECONOMIC SECURITY
}

\author{
ZORIANA BURYK
}

\begin{abstract}
Goal. Coverage of introduction of innovative concepts in the system of management of activity of sanatorium and resort enterprises. Research methodology. The following methods were used: analysis (theoretical review of scientific literature on the problem of research); a synthesis that made it possible to integrate individual parts of the facility into a single unit (development of a Balanced Scorecard for health resort enterprises in terms of socio-economic security); benchmarking that allowed us to map concepts (spa marketing, business performance management, and balanced scorecard). Results. The peculiarities of the management system of the sanatorium and resort enterprises in the conditions of social and economic security are considered. It is stated that the concept of management in terms of ensuring the socio-economic security of any enterprise of the sanatorium and resort complex is based on clearly formed systems of organization of management of socio-economic development. The basic methods of implementation, organization and management of social and economic security at the enterprise are distinguished. It is noted that spa marketing is a concept of management of the spa enterprise, which provides a comprehensive study of the needs of clients in the spa treatment and recreation for their fullest satisfaction through complex efforts to produce, sell and promote the spa product in a competitive market with the aim ensuring socio-economic security and profit. The basic processes covered by the concept of Business Performance Management for spa companies are presented. The Balanced Scorecard Balance Scorecard system has been developed for sanatorium and resort enterprises in terms of social and economic security. Scientific novelty. The basic innovative concepts (spa marketing, Business Performance Management and Balanced Scorecard) are proposed, which introduction into the enterprise management system will ensure effective management decisions, achievement of strategic goals, increase of profit and social and economic security in general. Practical importance. The introduction of our proposed concepts into the management system of sanatorium and resort enterprises will provide such an institution with a complete and effective implementation of processes for managing its activities, providing customer service and optimizing the functions and management procedures performed.
\end{abstract}

Keywords: enterprise, concept, management system, activity, safety. 


\section{INTRODUCTION}

Problem statement in general and its relevance to important scientific or practical tasks. The radical transformation of the state socio-economic system of Ukraine over the last two decades, significant economic transformations, changes in the organizational and legal forms of economic entities have contributed to significant changes in the san atorium and resort complex, contributed to the formation of market approaches to the management of sanatorium and resort enterprises, new technologies in resort service. The place of the sanatorium-resort complex in the system of public relations has also changed, which contributed to the systematic (primarily financial) withdrawal of the state from this sphere.

The decrease in the level of state regulation of the sanatorium and resort industry has influenced that the quality of service to the population, as well as the availability of sanatorium and resort services, now depend on the efficiency of functioning of certain subjects of the sanatorium and resort complex. New business conditions require participants of market relations of high business activity and new concepts in the management system.

Analysis of recent research and publications in which a solution of the problem to which the author refers. The study features management companies devoted to the works of G. Atamanchuk [1], V. Vasylenko [3], E. Dukhonin [8], D. Isaev [8], R. Kaplan [16-19], E. Mostovoy [8], D. Norton [16- 19], N. Podolchak [11], Y. Sytnik [12], V. Sitnichenko [13]. The study of management problems sanatorium and resort institutions are engaged in domestic and foreign scientists, such as: S. Voitovich [4], B. Gender, E. Krykavsky, O. Kuzmin, R. Murdik, L. Konechna [9], R. Russell, V. Romanovich, A. Sidorova, V. Stakhanov, K. Haksever, and others. The methodological and theoretical basis of the study are works devoted to the consideration and analysis of the state of socio-economic security of enterprises, mechanisms of organization and management of socio-economic security, the following scientists: O.V. Bazhenova [2], V. Geyets [5], V. Ortinsky [10].

Considering the current developments of the above research on this topic, however, should focus on issues that remain unresolved and insufficiently developed both in theoretical and practical aspects. These include the study of innovative concepts in the system of management of the activity of sanatorium and resort enterprises in the context of social and economic security.

\section{RESULTS}

Outline of the main research material with full justification of scientific results. The effective functioning of sanatorium and resort establishments while ensuring socio-economic security is determined by the conditions of their market activity, opportunities for the fullest satisfaction of the needs of end users of such services, and effective management of the UPC [11, p. 49]. The basis of their functioning, effective implementation of functions, methods and processes of management is based on the peculiarities of implementation of processes of management of such enterprises. They are implemented through the introduction of concepts in the system of activity management [4, p. 60].

The peculiarities of the management system of sanatorium and resort enterprises in the conditions of social and economic security include the following:

1) reflecting the processes and management procedures inherent in other service businesses, the management of health resorts (according to the purpose of operation), generates specific, specific features related to the provision of healthcare and some services, which, for their part, due to a sufficiently high level of standardization, do not allow flexible management (except regulation) [9];

2) considering the multidimensional nature of management within a spa resort, managers must simultaneously apply differentiated approaches, concepts, functions, management techniques that cannot always be combined or structured to formulate strategies at all levels. [1, c. 76];

3 ) as the processes of activity and customer service are combined in the sanatorium and resort establishment, the manager of the establishment and his assistants must not only be aware of the peculiarities of such service processes (economic, medical, service), used resources and technologies, 
but also possess appropriate competencies making effective management decisions (for example, managing an institution's marketing, medical treatment, or placement) [12];

4) organizational construction of the management system of the sanatorium and resort establishment has a block system that reflects the levels and ramifications of both the management structure and the sphere of managerial influence (according to the processes occurring in the institution) [13];

5) decision-making and management system in general spa facilities are characterized by a high degree of dependence on the market situation, customer load, level of government influence and regulation, and so managers often have to apply elements of situational management in managing such establishments [3, c. 87].

The concept of management in terms of ensuring the socio-economic security of any enterprise of the sanatorium-resort complex is based on clearly formed systems of organization of management of socio-economic development. Creation and implementation of the concept occurs from the very beginning of the establishment of the enterprise and in the subsequent process of conducting business activities. The effectiveness of the implemented concept is evaluated by theindicators of qualitative and timely ensuring the growth of socio-economic development of the enterprise and the volume of own resources, implementation of innovative technical equipment, ensuring financial stability and competitiveness. Also, the establishment of proper information for the subjects of management of sanatorium-resort enterprises, the system of organization and management of socio-economic security, the guarantee of information independence of managers, information security, economic efficiency, systematic. The concept of effective management of the socio-economic security of a spa resort also includes a set of methods for organizing, managing and preventing hazards and threats. The complex of methods and tasks of security management consists of: forecasting and identification of real dangers and threats; identify ways and methods of prevention; the elimination of the consequences of exposu re to dangers and threats; interaction of the enterprise with law enforcement and control bodies in order to prevent offenses; establishment of enterprise security service $[1 ; 5]$.

The main methods of implementation, organization and management of socio-economic security at the enterprise are [10, p. 156]:

- method based on the estimation of deviations of the limit indicators and observations on the current state of work at the enterprise;

- method based on the assessment of individual components of socio-economic security;

- method based on investment regulation and innovation: assessing the country's innovation potential by comparing quantitative and qualitative indicators with those of other countries;

- method that is based on the development of an economic intelligence system: an analysis is conducted and an economic intelligence system is formed to identify and minimize destabilizing and destructive factors of influence;

- method based on the diagnosis of current, tactical and strategic levels of socio-economic security.

The combination methods of management and socio-economic security of spa businesses can prevent and minimize the key threats to the provision of services related to the economic, technical, environmental, social enterprise components. In turn, the complex methods of prevention of dangers and threats are regulated by the following functions: forecasting, detection, prevention, mitigation of dangers and threats, security of activity of the enterprise and its personnel, preservation of property, creation of charitable competitive environment, elimination of consequences of the caused losses, etc. [1, p. 69].

As a result, the transition of the sanatorium-resort complex to market relations and the need to ensure socio-economic security have led to the introduction of management concepts in market management, one of which is marketing.

Sanatorium is a marketing management concept spa and resort company, which provides a comprehensive study of customer needs in a spa treatment and rest for their fullest satisfaction through integrated efforts of the production, sale and promotion of spa products in a competitive market to ensure social-economic security and profit [4, p. 62]. 
Marketing in the field of sanatorium services includes external, internal and interactive marketing. External marketing determines the work of the sanatorium on pricing, sales permits, promotion of sanatorium services. Internal marketing includes the whole complex of relations of the UPC administration with the staff (training, motivation, promotion, etc.), aimed at attracting every em ployee to marketing activities and providing high quality of vacationers service [1, p. 279].

Interactive marketing defines the ability of staff to serve the customer. Result of resort service pleasure of the recreation - consists not only of technological, but also functional component. The first component is the material part of the sanatorium product (the level of medical base, room comfort, catering, etc.), the second - directly the process of providing sanatorium services, in which the leading role is played by well-trained and motivated staff [4, p. 63].

One of the basic principles of marketing, including the marketing of UPC, is the principle of feedback. In addition to making economic decisions, depending on the market, recreational businesses actively influence consumers and com petitors by all possible methods and means. Thus, UPC does not passively respond to demand, but pursue a well-thought-out and well-coordinated policy of conquering the market, forming new consumers.

As a result, health resort marketing as a conceptual basis of the market system of management of the sphere of production of sanatorium and resort services takes into account the new conditions of the domestic resort market, which, under the influence of increasing the concentration of sectoral production, largely lose the chaotic nature inherent in this market and are subject to regulatory influences. the practice of resorts of traditional economic relations, in which the main role is given to the consumer.

From our point of view, in order to effectively manage and ensure socio-economic security, it is necessary to create a marketing service in the UPC.

Marketing services must equally successfully address a number of issues regarding the implementation of the accepted concept of marketing, as they represent the interests of the enterprise in the relationship with the consumer. Thus, the marketing department should be able to identify and identify market needs, outperform its competitors in identifying trends in needs development, refining them into ideas, and be actively involved in planning and developing a new resort product.

Marketing, as a new function of linking the UPC to the market, is based on a comprehensive and strategic approach to solving traditional problems. Organizational structures that are suitable for operational leadership may not meet the criteria necessary to implement a marketing strategy.

In general, there are two groups of marketing organizational structures: hierarchical (mechanical) and organic.

There are several types of hierarchical structures: linear, functional, linear-functional, divisional, mixed. UPC marketing services should be formed on a functional basis.

Functional structures are characterized by the distribution of personnel by functional blocks (Fig. 1).

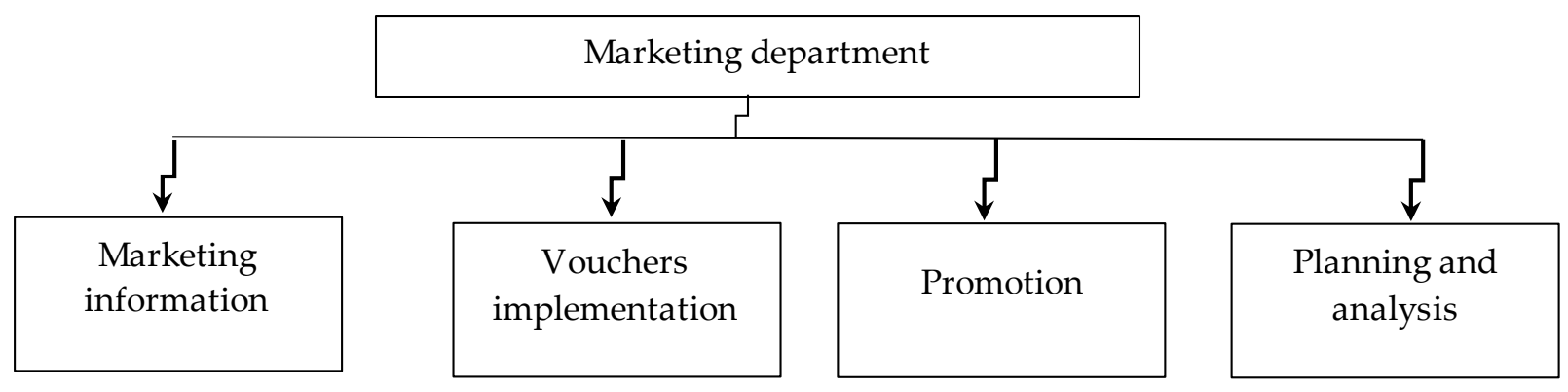

Fig. 1. Functional structure of the marketing department of the UPC

*compiled by the author based on [1; 4$]$

The basic principles of building a UPC marketing service are:

- simplicity;

- effectiveness of the system of links between units; 
- low sound;

- flexibility and adaptability.

The location of the marketing service in the organizational structure of the UPC and its relationship with other units deserves special consideration. It is optimal to attribute the marketing service to the headquarters subordinate directly to the first manager. There are variants of subordination of this service to the CFO or Special Vice President of Marketing. In any case, the particular importance of the marketing department for the UPC is due to the need for personal involvement, coordination and control by the CMO (Chief Medical Officer).

Nowadays, in order to be successful in a dynamic environment, UPC needs to be able to quickly adapt to changing market conditions and outperform its competitors in quality, speed of delivery, breadth of range and price of services, which in many respects provides a properly formulated concept in the management system.

By far, the most innovative concepts in the enterprise activity management system, incl. UPC is a Business Performance Management and Balanced Scorecard.

Business Performance Management (BPM) is a fundamentally new trend, known as "business performance management". It is a holistic, process-oriented approach to managerial decision-making, aimed at improving the enterprise's ability to assess its condition and manage its performance at all levels by combining owners, managers, staff and external contractors within a common integrated management environment [8, p. 65].

BPM is a concept that aims to optimize strategy implementation and consists of a set of integrated cyclical analytical processes supported by relevant technologies and relevant to both financial and operational information. BPM enables an enterprise to identify, measure and manage the effectiveness of its activities towards strategic goals. BPM's key financial and operational processes include planning, consolidation and reporting, analysis of key performance indicators and their dissemination within the enterprise [15].

Until some point, the evaluation tools for the efficiency of the enterprise were financial. Such instruments were financial statements. But according to research by R. Kaplan and his colleagues, these tools reflect the results of decisions and actions taken in the past and cannot be judged effective in the future. That's why the BPM concept was developed. It is closely linked to financial management. Financial performance is a universal indicator of business success, but not its driving force. To reflect the true results of an enterprise at a certain point in time, a link between them and financial results is required. Waiting to report for a month or a quarter is too long, given that these are figures that affect daily activities. A rapid feedback mechanism is required to be able to coordinate, correct, or direct the work of a particular department of the enterprise whose activities need to be aligned with the overall strategy [6].

As a result, from our point of view, this concept in the system of management of activity of the UPC is useful for the whole enterprise, as it allows the staff to know exactly what they are required and expected. This is due to the fact that individual em ployees are able to evaluate the effectiveness of their activities and use a feedback mechanism to identify areas that need improvement. Such operational feedback reduces the time for decision making and error correction. The results are the best operational efficiency and benefits of the UPC.

The main processes covered by the BPM concept can be seen in Table 1.

Thus, the introduction of the concept of BPM in the management system of activities of sanatorium and resort enterprises in terms of socio-economic security can be expected: improving the quality of reporting and analytics, leading to greater financial transparency, improving the interaction of divisions of the UPC, reducing reporting cycles, which improves the ability respond to changes and threats, reduce the number of errors; more rigorous process management leading to better control; the ability to increase the time to analyze data by reducing the time to manage it. 


\begin{tabular}{|c|l|}
\hline \multicolumn{1}{|c|}{ Process } & \multicolumn{1}{|c|}{ Content } \\
\hline Strategize & $\begin{array}{l}\text { Allows managers of sanatorium and resort establishments to } \\
\text { develop strategies and bring them to business units, identify } \\
\text { opportunities for value creation and create a system of } \\
\text { documents that provides an assessment of management } \\
\text { effectiveness and its dynamics }\end{array}$ \\
\hline Plan & $\begin{array}{l}\text { Helps managers of all UPC units set their local goals, } \\
\text { develop and simulate planning scenarios, create programs and } \\
\text { budgets that support operations, and set targets for different } \\
\text { metrics over different time periods }\end{array}$ \\
\hline Monitor and analyze & $\begin{array}{l}\text { Allows to evaluate individual and group performance using } \\
\text { relevant key metrics at all levels of the UPC, as well as providing } \\
\text { users with additional information to help them take action }\end{array}$ \\
\hline Take corrective actions & $\begin{array}{l}\text { Helps UPC managers respond to emerging situations and } \\
\text { threats in a timely manner }\end{array}$ \\
\hline
\end{tabular}

Tab. 1. The main processes covered by the BPM concept for sanatorium and resort enterprises * compiled by the author based on [3; 14]

The concept of Balanced Scorecard, or "Balanced Scorecard", is one of the latest advances in modern management science. Its authorship is owned by David Northon (David Northon) and Robert Kaplan (Robert Kaplan), who in 1992 published an article in The Harvard Business Review "The Balanced Scorecard - Measures That Drive Performance" [16; 17; 18].

The advantage of the Balanced Scorecard concept is that it gives senior management a completely new management tool that translates overall enterprise strategies into a set of interconnected strategic goals, programs to achieve them, and correspondingly balanced metrics that evaluate the achievements of these units across four major projections: finance, consumers, internal processes, learning and growth. The system of Balanced Scorecard indicators for sanatorium and resort enterprises in terms of socio-economic security can be seen in Fig. 2.

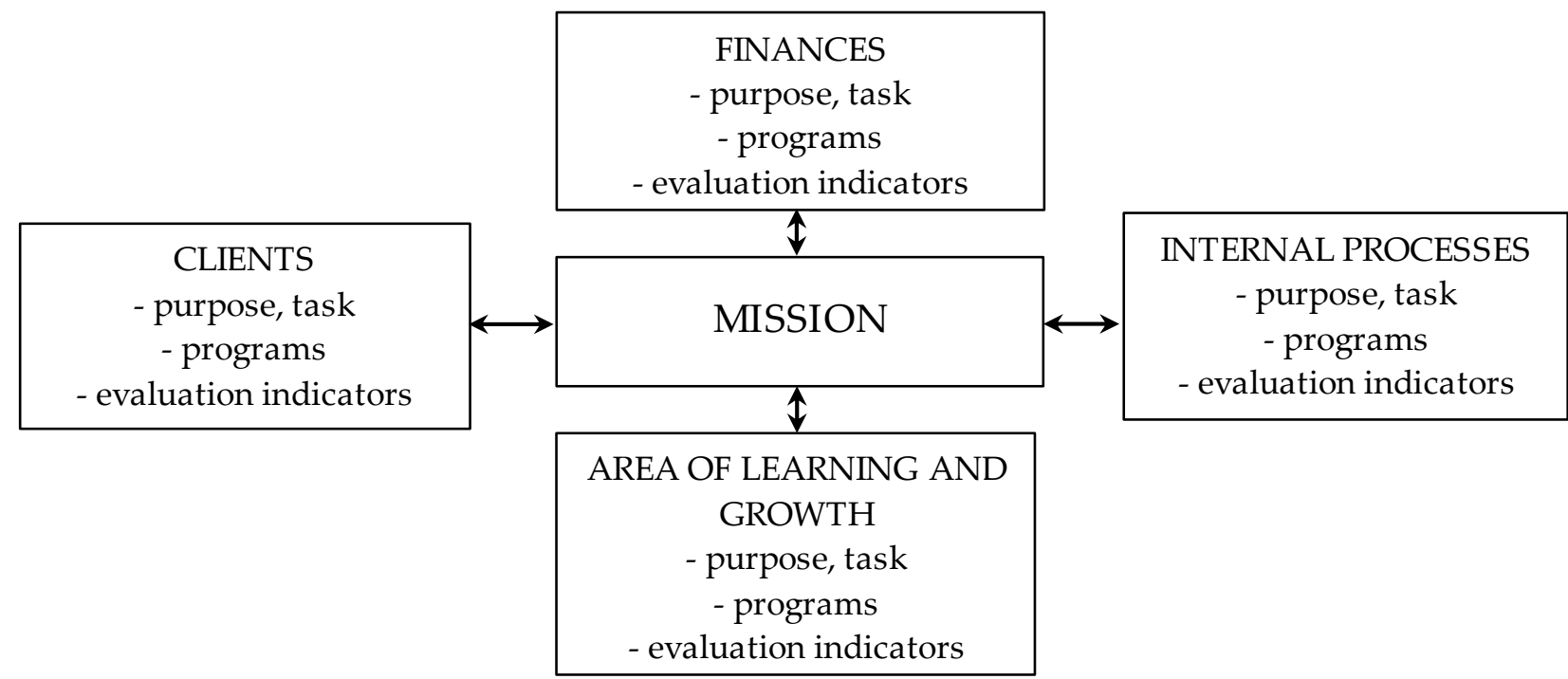

Fig. 2. Balanced Scorecard for sanatorium enterprises in the socio-economic security

* compiled by the author based on [7; 16; 17]

Studies conducted on the BSC concept indicate that it reflects the core activities of spa businesses such as customer service, operational and financial efficiency - in the form of a set of performance indicators - Key Performance Indicators (KPI). Their number should be 20-25 (financial indicators, indicators of the client component and training and growth are approximately $22 \%$, indicators of internal processes - 34\%). The enterprise captures and analyzes these indicators to understand whether strategic goals are being achieved or not [19]. 
A significant advantage of the Balanced Scorecard is the use of not only financial but also nonfinancial performance indicators of the enterprise to evaluate customer satisfaction, internal processes efficiency, employees' potential to ensure socio-economic security and long-term financial success. However, the number of Balanced Scorecard projections and estimates presented is rather limited and can be greatly expanded depending on the industry of the enterprise. Also, existing projections can be adjusted - generalized or more narrowly oriented - depending on the specific activity of the enterprise. However, it can be noted that the presented concept does not require much adaptation and can successfully operate in the resorts of Ukraine.

\section{CONCLUSIONS}

Conclusions from this study and prospects for further development in this direction. Thus, our proposed concepts in the management system of sanatorium and resort enterprises, taking into account the above features will allow such an institution to fully and effectively perform the processes of managing its activities, customer service and provide optimization of functions and management procedures.

A promising direction for further research is the construction of a methodology for assessing the quality of management of the sanatorium and resort enterprise.

\section{REFERENCES}

[1] Atamanchuk G.V. Upravlenie: suschnost, tsennost, effektivnost: ucheb. posob. Akademycheskyi Proekt: Kultura, Moskva, 2006. (in Russian)

[2] Bazhenova O.V. Analiz stanu ekonomiky Ukrainy v konteksti yii ekonomichnoi bezpeky. Problems of Foreign Economic Relations Development and Attraction of Foreign Investments: Regional Aspect, (2004), 839_ 845. (in Ukrainian)

[3] Vasylenko V.O. Sytuatsiinyi menedzhment: Navch. Posibnyk. TsNL, Kyiv, 2005. (in Ukrainian)

[4] Voitovych S. Features of the Organizational Construction of System of Management of SanatoriumResort Institution. Economic Journal Lesya Ukrainka Eastern European National University, 4 (2016), 60-66. Available at: http://nbuv.gov.ua/UJRN/echcenu_2016_4_12 (in Ukrainian)

[5] Heits V.M. Modeliuvannia ekonomichnoi bezpeky: derzhava, rehion, pidpryiemstvo. VD «INZhEK», Kharkiv, 2006. (in Ukrainian)

[6] Interview with Robert D. Kaplan, (2019). Available at: https://thediplomat.com/2014/03/interview-withrobert-d-kaplan/

[7] Information Project Balanced Scorecard BKG company, (2019). Available at: https://balancedscorecard.org/bsc-basics-overview/

[8] Duhonin E.Yu., Isaev D.V., Mostovoy E.L. Kontseptsiya Business Performance Management: nachalo puti. Alpina Biznes Buks, Moskva, 2004. (in Russian)

[9] Nakonechna L.D. Principles of formation of the integrated control system of quality in medical institution of sanatorium type. Scientific reports National Agriculture University of Ukraine, 4 (5) (2006), 182-190. Available at: http://nd.nubip.edu.ua/2006-4/06nldami.html (in Ukrainian)

[10] Ortynskyi V.L. Ekonomichna bezpeka pidpryiemstv, orhanizatsii ta ustanov. Pravova yednist, Kyiv, 2009. (in Ukrainian)

[11] Podolchak N.Y. Socioeconomic effeciency of enterprise management. Actual Problems of Economics, 2 (140) (2013), 47-56. (in Ukrainian)

[12] Sytnyk Y.S. Conceptual grounds for intellectualization of enterprise management systems. Actual Problems of Economics, 8 (134) (2012), 198-208. (in Ukrainian)

[13] Sytnichenko V., Kiselova A. Suchasni systemy menedzhmentu - osnova staloho rozvytku pidpryiemstva. Standartyzatsiia, sertyfikatsiia, yakist, 3 (2004), 59-61. (in Ukrainian)

[14] Parahina V.N., Maksimenko L.S., Panasenko S.V. Strategicheskiy menedzhment. KNORUS, Moskva, 2012. (in Russian)

[15] Business Performance Management Industry Framework Document, 5.0. BPMStandards Group, 2005. 
[16] Kaplan R.S., Norton D.P. The Balanced Scorecard: Translating Strategy into Action. Harvard Business School Press, Boston, 1996.

[17] Kaplan R.S., Norton D.P. The Balanced Scorecard - Measures That Drive Performance. Harvard Business Review, January-February (1992), 71-79.

[18] Kaplan R.S., Norton D.P. Using the Balanced Scorecard as a Strategic Management System. Harvard Business Review, July-August (2007), 75.

[19] Kaplan R.S. Organization-oriented strategy. How do organizations succeed in the new business environment applying the Balanced Scorecard. Olimp-biznes, Moskow, 2004.

Address: Zoriana Buryk, Vasyl Stefanyk Precarpathian National University, 57, Shevchenko Str., IvanoFrankivsk, 76018, Ukraine.

E-mail: z.burik@ukr.net

Received: 04.06.2019; revised: 19.11.2019.

Бурик Зоряна. Впровадження інноваційних концепцій в систему управління санаторно-курортним підприємством в контексті забезпеченн я соціально-економічної безпеки. Журнал Прикариатського університету імені Василя Стефаника, 6 (3-4) (2019), 29-36.

Метою дослідження є висвітдення впровадження інноваційних концепцій в систему управління діяльністю санаторно-курортних підприемств. Використовувадися наступні методи: аналіз (теоретичний огдяд наукової дітератури з проблеми дослідження); синтез, котрий до зводив інтегрувати окремі частини об'єкта в єдине ціле (розробка збалансованої системи показників для санаторно-курортних підприємств 3 точки зору соціально-економічної безпеки); бенчмаркінг, що дозводив зіставити поняття (санаторно-курортний маркетинг, управління ефективністю бізнесу, збалансована система показників). У статті розглянуто особливості системи управління санаторнокурортними підприємствами в умовах соціально-економічної безпеки. Стверджується, що концепція управління в частині забезпечення соціально-економічної безпеки будь-якого підприємства санаторно-курортного комплексу базується на чітко сформованих системах організації управління соціально-економічним розвитком. Виділено основні методи реалізації, організації та управління соціально-економічною безпекою на підприємстві. Відзначається, що санаторно-курортний маркетинг - це концепція управління санаторно-курортним підприємством, яка передбачає всебічне вивчення потреб клієнтів у санаторно-курортному лікуванні і відпочинку для їх найбільш повного задоволення допомогою комплексних зусиль з виробництва, реалізації і просування санаторнокурортного продукту на конкурентному ринкуз метою забезпечення соціально-економічної безпеки і отримання прибутку. Представлені основні процеси, що охоплюються концепцією управдіння ефективністю бізнесу для санаторно-курортних компаній. Система збалансованих показників розроблено для санаторно-курортних підприємств з точки зору соціально-економічної безпеки. Запропоновано основні інноваційні концепції (спа-маркетинг, управління ефективністю бізнесу та збалансована система показників), впровадження яких у систему управління підприємством забезпечить прийняття ефективних управлінських рішень, досягнення стратегічних цілей, підвищення прибутку та соціально-економічної безпеки в цілому. Впровадження пропонованих нами концепцій в систему управління санаторно-курортними підприємствами забезпечить такій установі повну та ефективну реалізацію процесів управління його діяльністю, забезпечення обслуговування кдієнтів та оптимізацію виконуваних функцій і процедур управління.

Кдючові слова: підприємство, концепція, система управління, діядьність, безпека. 